\title{
An Evaluation of the Maintenance of Peace and Order in Nueva Ecija Provincial Jail
}

\author{
Mary Chris A. Austria-cruz, MA. Cecilia P. Reyes
}

\begin{abstract}
The study was conducted in the Nueva Ecija Provincial Jail (NEPJ) located at Caalibangbangan, Cabanatuan City, Nueva Ecija. Ninety (90) inmates and ten (10) jail personnel served as respondents of the study. The NEPJ provides the strict implementation of the rules and regulations in the custody and security of inmates. Both provincial personnel and inmates know that all the security procedures in the jail activities are highly implemented. A prisoner accused of breaking the rules does not have all the rights during the trial because a prison disciplinary proceeding is not the same as in criminal prosecution [1]. Among other things, the researchers recommended that the administration of NEPJ should continue the way and manner on how they provide very effective security operation, as well as in maintaining the activities that help the inmates make a better relationship with the provincial jail and other inmates.
\end{abstract}

Keywords - inmates, peace and order, provincial jail, security procedure and strict implementation.

\section{INTRODUCTION}

The correctional institution is the 4th pillar in the Philippines Criminal Justice System to address the growing concern of jail management and penology problems. Primarily, its clients are detainees accused before a court who are temporarily confined in such jails while undergoing investigation, waiting for final judgment and those who are serving a sentence promulgated by the court three (3) years and below [2].

The Bureau of Correction has four major areas of the rehabilitation program, namely; Livelihood, Educational and Vocational Training, Recreation and Sports, and Religious Activities. These Programs are being continuously implemented to eliminate the offender's pattern of criminal behavior and to reform them to become a law-abiding and productive citizen.

The Bureau of Jail Management and Penology was created on January 2, 1991, pursuant to Republic Act 6975 otherwise known as the "DILG ACT OF 1990"[2]. It is mandated to replace its forerunner, the office of Jail Management and Penology of the Philippine Constabulary/integrated International Police. The BJMP has jurisdiction over alldistrict, cities and municipal jails. It is a line bureau of the Department of Interior and Local Government (DILG). As such, it ensures the establishment of secure, clean, adequately equipped and sanitary facilities and provision of quality service for the custody and safekeeping and development of district, city, and municipal inmates, and fugitive from justice or person detained, awaiting or undergoing investigation or trial and/ or transfer to the national penitentiary, and/ or violent mentally ill person who endangers himself/herself or the safety of others as certified by proper medical officer pending transfer to a mental institution.

The Philippine government, despite many difficulties, has taken and continuously takes concrete moves towards the improvement of its prison/jail conditions and the treatment of the offenders [3]. The author in [3] says "the government cannot do this alone. It needs the cooperation and active involvement of all sectors in our society/media, academy, business, etc. prison reforms can only achieve through the active participation of all the members of society. Each one has a responsibility in making these reforms possible."

Decent and humane prison conditions can be realized, and prisoners can be successfully rehabilitated if every sector of society will work together [4]. An offender must afford his or her rights throughout the different stages of the criminal Justice System from the commission of the offense, to investigation and apprehension, to prosecution, trial and conviction and finally punishment and correction. The Community, specifically, plays a significant role in the administration of criminal justice as it functions even before the commission of the offense.

The primary agency tasked to enforce the laws of the Philippine prison is the Bureau of Prisons under the Department of justice. The Prison law, which is implemented by the Bureau of Prisons, is found in section 1705 to 1751 of Revised Administrative Code, which renamed the Bureau of Prison as the Bureau of Corrections under Executive order 
292 passed during the Aquino administration. To maintain peace and order inside the Bureau of Corrections, different measures were implemented by the department.

In Nueva Ecija, the agency tasked to implement the law of the Philippine prison is the Nueva Ecija Provincial Jail. In this regard, the researchers look into the implementation of the said law in their province. They aimed to evaluate the peace and order being implemented in the jail which was not investigated by other researchers in the province. Thus, this study finds meaning and relevance.

\section{METHODOLOGY}

This study used a descriptive research design. According to [5], as cited by the authors in [6] and [7], "descriptive research systematically describes a situation, problem, phenomenon, service or program, attitudetoward an issue or simply, it provides information on a subject". This study described the true picture of the maintenance of peace and order in Nueva Ecija Provincial Jail.

The respondents of the study were chosen purposively based on the following criteria [8]: they must be Jail Personnel and Detainees in Nueva Ecija Provincial Jail, Caalibangbangan, Cabanatuan City, at least 3 years working as jail personnel and at least three years as an inmate.

The picked respondents were ninety (90) inmates and ten (10) personnel.

The data came from the researchers-made questionnaire answered by the respondents.

The study was done from September 2018 to February 2019. It did not include personal reasons of inmates how and why they are in Nueva Ecija Provincial Jail.

\section{RESULTS AND DISCUSSION}

\section{Crimes Committer by the Inmates}

Table 1 shows the crimes committed by the 90 inmate respondents. 35 inmates committed drug-related cases and another 35 under the category of "others" with 38.89 percentages, 13 inmates committed estafa with 14.44 percentage and 7 inmates who committed robbery with $7.78 \%$. The highest number of crimes committed by inmates are drug-related and under the category of "others".The finding proved that drug-related cases are one of the serious problems of the province of Nueva Ecija which is also the major crime concern in the country.

Table.1: Crimes Committed by the Inmates

\begin{tabular}{|c|c|c|}
\hline $\begin{array}{c}\text { Inmates } \\
\text { (Crimes Committed) }\end{array}$ & Frequency & Percentage \\
\hline Drug-Related & 35 & 38.89 \\
\hline Estaffa & 13 & 14.44 \\
\hline Robbery & 7 & 7.78 \\
\hline Others & 35 & 38.39 \\
\hline TOTAL & 90 & $100 \%$ \\
\hline
\end{tabular}

\section{Rights and Privileges of Inmates}

Table 2 shows the rights and privileges of inmates in Nueva Ecija Provincial Jail. The table clearly showed that the rights and privileges of the inmates were respected and implemented particularly the "right to receive visitors during visiting hours" with a weighted mean of 3.73 and verbally described as strongly agree.

Table.2: Rights and Privileges of Inmates

\begin{tabular}{|ll|c|c|}
\hline \multicolumn{1}{|c|}{ Item Statement } & $\begin{array}{c}\text { Weighted } \\
\text { Mean }\end{array}$ & Verbal Interpretation \\
\hline 1. & The right to be treated as a human being & 3.68 & Strongly Agree \\
\hline 2. & The right to avail medical and other health services & 3.68 & Strongly Agree \\
\hline 3. & $\begin{array}{l}\text { The right to practice his/her religious belief and } \\
\text { cultural perception }\end{array}$ & 3.68 & Strongly Agree \\
\hline 4. & The right to vote unless disqualified by law & 3.45 & Strongly Agree \\
\hline 5. & The right to receive visitors during visiting hours & 3.73 & Strongly Agree \\
\hline \multicolumn{2}{|c|}{ OVERALL WEIGHTED MEAN } & 3.64 & Strongly Agree \\
\hline
\end{tabular}

\section{Custody, Security and Control}

Table 3 depicts the custody, security and control being implemented in Nueva Ecija Provincial Jail. The table clearly depicted that they have highly implemented specifically the "conduct of regular counting of inmates at least four (4) times in twenty four (24) hours period" and "the security of firearms and anti-riot equipment in the armory". 
Table 3. Custody, Security and Control of the NEPJ

\begin{tabular}{|ll|c|c|}
\hline \multicolumn{1}{|c|}{ Item statement } & $\begin{array}{c}\text { Weighted } \\
\text { Mean }\end{array}$ & $\begin{array}{c}\text { Verbal } \\
\text { Interpretation }\end{array}$ \\
\hline 1. & Never allow the jail officer to open the inmate's quarters alone & 3.57 & Strongly Agree \\
\hline 2. & $\begin{array}{l}\text { Maintain a system of key control, inmates are not allowed to } \\
\text { handle keys. }\end{array}$ & 3.65 & Strongly Agree \\
\hline 3. & Maintain strict control of firearms. & 3.63 & Strongly Agree \\
\hline 4. $\quad$ Secure firearms and anti-riot equipment in the armory. & 3.74 & Strongly Agree \\
\hline 5. $\quad \begin{array}{l}\text { Conduct regular counting of inmates at least four (4) times in } \\
\text { twenty-four (24) hours period }\end{array}$ & 3.80 & Strongly Agree \\
\hline \multicolumn{2}{|l|}{ OVERALL WEIGHTED MEAN } & 3.72 & Strongly Agree \\
\hline
\end{tabular}

\section{Security Procedures during Jail Activities}

Table 4 shows the weighted mean of 3.46 and a verbal interpretation of strongly agree. it can be said that there is tight security in the provision of Inmates Welfare and Development Program (IWDP).

Table.4: Security Procedures during Jail Activities

\begin{tabular}{|cl|c|c|}
\hline \multicolumn{2}{|c|}{ Item statement } & $\begin{array}{c}\text { Weighted } \\
\text { Mean }\end{array}$ & $\begin{array}{c}\text { Verbal } \\
\text { Interpretation }\end{array}$ \\
\hline 1. & Inmates are supervised by jail personnel during a meal. & 2.96 & Agree \\
\hline 2. & Individual mess utensils of an inmate are made of plastic. & 3.46 & Strongly Agree \\
\hline 3. & $\begin{array}{l}\text { Supervise inmates during livelihood, educational, religious, } \\
\text { sports and recreational activities }\end{array}$ & 3.52 & Strongly Agree \\
\hline 4. $\quad$ Inmate's letters are censored by authorized jail personnel & 3.59 & Strongly Agree \\
\hline 5. $\quad$ Personnel search and identify inmate's visitors upon entry to jail & 3.77 & Strongly Agree \\
\hline & OVERALL WEIGHTED MEAN & 3.46 & Strongly Agree \\
\hline
\end{tabular}

\section{Movement/Transfer of Inmates and Security}

The security measures in terms of movement and transfer of inmates given in Nueva Ecija Provincial Jail are highly implemented. Inmates being moved are properly handcuffed before transfer. All inmates are not allowed to use personal vehicles for their movement or transfer. They are not allowed to go to a washroom or toilet alone.

\section{CONCLUSIONS AND RECOMMENDATIONS}

The lowest average in rights and privileges of inmates is the right to vote unless disqualified by law. In custody, security and control, the NEPJ never allow the officer to open the inmate's quarters alone. Among the five-item statements under the movement/transfer of inmates, the lowest weighted mean is under the statement of "any movement of inmates to another penal establishment shall be treated confidently", which implies that there's a possibility of escaping if it is known by the public. While in security procedures during jail activities are the item which stated about the supervision of inmates by the NEPJ Personnel during a meal, therefore we conclude that this item statement is not well supervised inside the Nueva Provincial Jail.

In the light of the above findings the following recommendations were drawn: 1.the management of Nueva Ecija Provincial Jail should inform and explain to all inmates about their rights to vote during elections even they are inside the NEPJ; 2. give orientation to all NEPJ Personnel about the opening of inmates' quarters alone, for the purpose of their safety and to avoid any harm and disturbances that can possibly occur; 3. the management of Nueva Ecija Provincial Jail should set techniques and plans on how they transfer inmates without the knowledge of public people; 4. strengthen the policy of Nueva Ecija Provincial Jail in security and discipline of inmates during mealtime to avoid problems regarding meal; 5 . Conduct seminars and trainings about the new concept of rehabilitation of inmates; and 6. For 
future researchers, increase the number of respondents and extend the scope of the study for more accurate result and to make accurate decisions given available information [9] in running the NEPJ.

\section{REFERENCES}

[1] Michael B. Mushlin, (2002), Rights of Prisoners. 3d ed. St. Paul, Minn.: Thomson/West

[2] Jake De Vera Guntalilib, (2016), Personalities in Correction

[3] Mildred Bernadette BaquilodAlvor, (2016), The Philippine Corrections System: Current Situation And Issues

[4] Former Supreme Court Chief Justice Andres R. Narvasa. Handbook on the Courts, and the Criminal Justice System (1996)

[5] Kumar, R. Research Methodology: A step-by-step guide for beginners (4th.ed.) SAGE,CA: ThousandOaks.2014.

[6] Subia, G.S., Trinidad, C.L., Pascual, R.R., Medrano, H.B. \&Manuzon, E.P. Learning Styles and Preferred Teaching Styles of Master of Arts in Teaching (MAT), major in Vocational Technological Education (VTE) Generarion Y Learners.International Journal of English Literature and Social Sciences (IJELS) .Vol-4, Issue 2, Mar-Apr, 2019. https://dx.doi.org/10.22161/ijels.4.2.35.

[7] Jocson, J., Florencondia, N. and Subia, G. (2019).Flood Prevention and Mitigation Initiatives towards aFlood-Free City. American Scientific Research Journal for Engineering, Technology, and Sciences (ASRJETS) (2019) Volume 58, No 1 , pp 215-224.

[8] Subia, G. (2018) Comprehensible Technique in Solving Consecutive Number Problems in Algebra. Journal of Applied Mathematics and Physics, 6, 447-457. doi: 10.4236/jamp.2018.63041.

[9] Subia, Gener S. Think Like My Teacher (TLMT): A New Method in Assessing Millennial Learners.International Journal of Arts, Humanities and Social Sciences.Volume 3.Issue 1.2018. 57-61.www.ijahss.com 